\title{
Graft versus host disease following small bowel and abdominal wall transplantation
}

\author{
Gurdeep S Mannu, Anil Vaidya
}

- Additional material is published online only. To view please visit the journal online (http://dx.doi.org/10.1136/bcr2014-205983)

Department of Transplantation Surgery, Oxford University Hospitals, Oxford, UK

\section{Correspondence to} Dr Gurdeep S Mannu, gurdeepmannu@gmail.com

Accepted 9 September 2014

\section{DESCRIPTION}

A 24-year-old man with short gut syndrome due to severe fistulating Crohn's disease, underwent a simultaneous isolated small bowel and abdominal wall transplantation. He had Campath- $1 \mathrm{H}$ induction and tacrolimus as maintenance immunosuppression. On day18 postoperatively, he presented with increasing shortness of breath and a diffuse macular, blanching, erythematous eruption rash on his trunk and back (host), however sparing the transplanted abdominal wall skin (graft). A chest radiograph is shown in online supplementary figure S1. Differential diagnosis included viral exanthema and drug reaction with eosinophilia and systemic symptoms (DRESS) and more importantly graft versus host disease (GVHD).

Since the donor allograft abdominal wall was completely unaffected (figure 1), along with a macrochimeric picture in the peripheral blood, $(4 \%$ CD3 expressing lymphocytes from donor origin), a diagnosis of GVHD was made. Punch biopsy of the rash was inconclusive. He was given three doses of intravenous $500 \mathrm{mg}$ methylprednisolone and $10 \mathrm{mg}$ prednisolone daily added to his maintenance immunosuppressive regimen. The rash and the respiratory symptoms resolved with this treatment (figure 2).

GVHD following intestinal transplantation has an incidence between $5 \%$ and $9 \%$ of adult intestinal transplants. ${ }^{1} 2$ It is a rare, complex condition that results from alloactivation of transplanted immunocompetent donor lymphoid cells to recipient tissue. ${ }^{3}$ It is progressive and can be fatal if not diagnosed and managed early with adequate escalation of immunosuppression. ${ }^{1} 2$ The skin of the abdominal wall transplant (graft) can help in the early diagnosis of GVHD since it may not be involved in the rash.

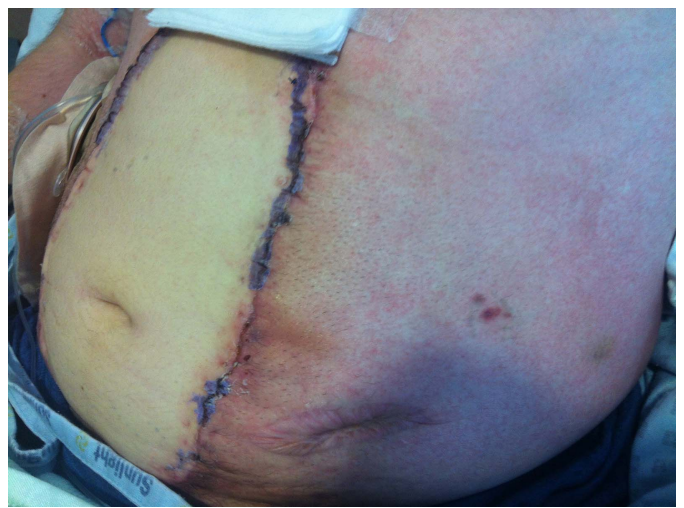

Figure 1 The rash on recipient skin. Note that the abdominal wall transplant is spared.

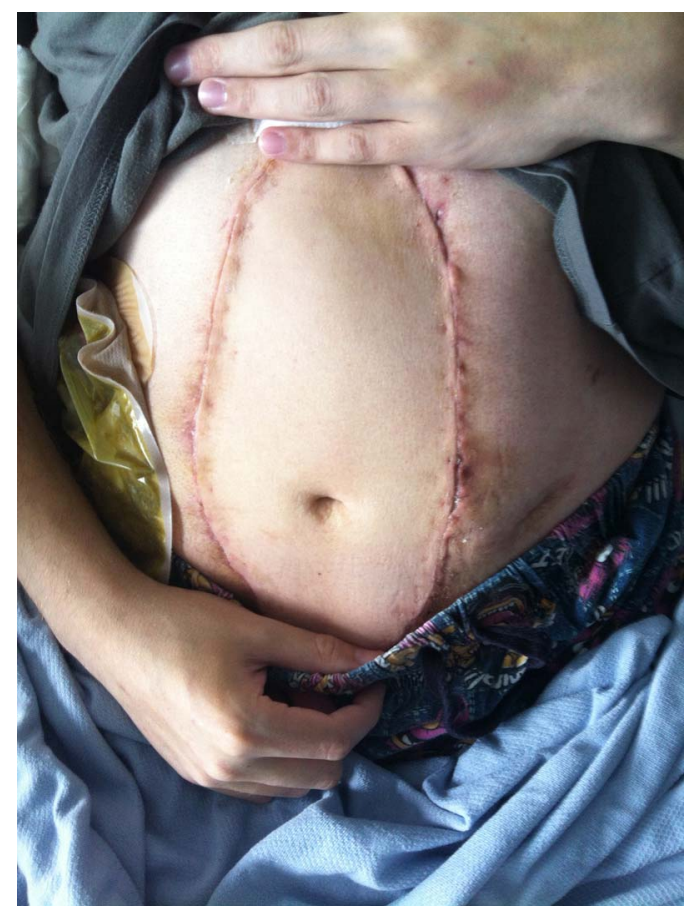

Figure 2 The rash improved with treatment over several days.

\section{Learning points}

- Graft versus host disease (GVHD) is a rare, progressive and potentially fatal condition that results from complex mechanisms of alloactivation of transplanted immunocompetent donor lymphoid cells to recipient tissue.

- GVHD can be difficult to distinguish from other dermatological conditions and so a high index of suspicion must be held in patients presenting with a rash post-transplantation.

- The treatment involves high-dose steroid therapy intravenously in the acute setting with optimisation of immunosuppression treatment.

Competing interests None.

Patient consent Obtained.

Provenance and peer review Not commissioned; externally peer reviewed.

\section{REFERENCES}

1 Mazariegos GV, Abu-Elmagd K, Jaffe R, et al. Graft versus host disease in intestinal transplantation. Am J 2004;4:1459-65.

2 Wu G, Selvaggi G, Nishida S, et al. Graft-versus-host disease after intestinal and multivisceral transplantation. Transplantation 2011;91:219-24

3 Reyes J, Todo S, Green M, et al. Graft-versus-host disease after liver and small bowel transplantation in a child. Clin Transplant 1997;11(5 Pt 1):345-8. 
Copyright 2014 BMJ Publishing Group. All rights reserved. For permission to reuse any of this content visit http://group.bmj.com/group/rights-licensing/permissions.

BMJ Case Report Fellows may re-use this article for personal use and teaching without any further permission.

Become a Fellow of BMJ Case Reports today and you can:

- Submit as many cases as you like

- Enjoy fast sympathetic peer review and rapid publication of accepted articles

- Access all the published articles

- Re-use any of the published material for personal use and teaching without further permission

For information on Institutional Fellowships contact consortiasales@bmjgroup.com

Visit casereports.bmj.com for more articles like this and to become a Fellow 